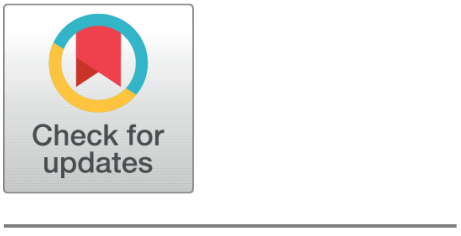

open ACCESS

Received: 26.05.2021

Accepted: 12.07.2021

Published: 01.09.2021

Citation: Ekwueme OU, Obiora DN, Okeke FN, Ibuot C (2021)

Environmental assessment of gully erosion in parts of Enugu north, Southeastern Nigeria. Indian Journal of Science and Technology 14(29): 2400-2409. https://doi.org/ 10.17485/IJST/v14i29.933

* Corresponding author.

ekwueme_oliver@yahoo.com

Funding: None

Competing Interests: None

Copyright: (c) 2021 Ekwueme et al. This is an open access article distributed under the terms of the Creative Commons Attribution License, which permits unrestricted use, distribution, and reproduction in any medium, provided the original author and source are credited.

Published By Indian Society for Education and Environment (iSee)

ISSN

Print: 0974-6846

Electronic: 0974-5645

\section{Environmental assessment of gully erosion in parts of Enugu north, Southeastern Nigeria}

\author{
Oliver U Ekwueme ${ }^{1 *}$, Daniel N Obiora ${ }^{1}$, Francisca N Okeke ${ }^{1}$, johnson C Ibuot $^{1}$ \\ 1 Department of Physics and Astronomy, University of Nigeria, Nsukka Enugu State
}

\section{Abstract}

Objectives: To assess gully erosion in parts of Enugu north, Southeastern Nigeria using some geotechnical parameters. Method: The soil samples were collected from different gully point and some geotechnical parameters was analyzed in Soil Science Department, University of Nigeria in accordance with the specified standard procedures. Finding: The assessment of gully erosion in parts of Enugu north, southeastern Nigeria, has been carried out. Soil samples were collected from the four major gully points, at the depth range of 0.5 to 1.0 $\mathrm{m}$ using soil auger, core samplers and hammer. The soil classification shows that the textural characteristics were predominantly sandy, loamy and clayey. Liquid limit (LL) ranged from 16.67 to $46.89 \%$. Plastic limit (PL) was $33.45 \%$ in Igbo-Eze South and $22.38 \%$ in Nsukka. None plastic limit were observed in IgboEze North and Udenu. Percentage plasticity index (PI) of $13.44 \%$ was depicted in Igbo-Eze South and $9.90 \%$ in Nsukka. Zero plasticity indexes were noted in Igbo-Eze North and Udenu. Bulk density test ranged from 1.39 to $1.56 \mathrm{~g} / \mathrm{cm}^{3}$. Porosity ranged from 41.13 to $47.55 \%$. The hydraulic conductivity and moisture content are ranged from 8.89 to $22.73 \mathrm{~m} /$ day and 7.07 to $31.73 \%$ respectively. These results indicate presence of coarse sand, fine sand, low amount of clay and silt in small proportion, loosed soil with low binding materials, instability of soil structure, low moisture content and other bio-activities that contribute to the rate of increase of gully erosion in the study area. Novelty : The estimated geotechnical parameters, including Atterberg limit (plastic limit, liquid limit and plasticity index), hydraulic conductivity of the soil, soil aggregate stability, particle size distribution, bulk density, total porosity proffers solutions to the gully problem in the area.

Keywords: Enugu north; gully erosion; geotechnical

\section{Introduction}

One of the geological hazards predominantly known in Enugu state, southeastern Nigeria, is the disastrous effects of gully erosion. Gully erosion is natural geologic hazards which occurs when the layers of soil is detached and transported by 
natural agents such as running water, wind, etc., which normally results in soil loss, land degradation, dissection of road and affect agricultural productivity. However, Southeastern Nigeria is one of the regions that are known with calamitous effect of the gully erosion. ${ }^{(1)}$ maintain that geologic hazard has been a serious environmental problem in the southeastern Nigeria, causing the degradation of lands, and destruction of civil engineering infrastructures. Gully erosion hazard has remained active over the years, devastating the physical ecology of large part of southeastern Nigeria by ${ }^{(2,3)}$ noted that the formation of gullies is one of the greatest environmental disasters in Nigeria especially Southeastern zone, destroying agricultural land and constitute a menace in community-based development. ${ }^{(4)}$ observed that gully erosion is an endemic environmental problem in southeastern Nigeria. ${ }^{(5)}$ stated that geologic erosion constitutes a serious problem in southeastern Nigeria. ${ }^{(6)}$ indicated that the highest concentration of severe gully erosion in Nigeria is found in five Eastern states; Anambra, Enugu, Abia, Imo, and Akwa Ibom. Gully erosion in Southeast Nigeria has continued to pose a challenge to Geoscientist and other environmental scientist by ${ }^{(7,8)}$ identified that the gully erosion is of major concern in the southeastern part of Nigeria. Gully erosion has become one of the worst environmental disasters that many towns and villages in Southeastern Nigeria had to contend with over the years by ${ }^{(9)}$ and ${ }^{(10)}$. Southeastern part of Nigeria is more affected by erosion than its northeastern counterpart by ${ }^{(11)}$. However, previous research has shown that one of the causes of gully erosion in most of the area; especially in southeastern Nigeria is the human activities on the soil and geotechnical parameters of the soil within the area. ${ }^{(2)}$ evaluated geologic conditions and geotechnical parameters that influence the formation of gullies at Ekwulobia, Oko and Nanka Towns of Southeastern Nigeria, and indicate that soil materials (lithology) which are mostly loosed sands with low percentage of silt/clay fractions are the cause of gully erosion in the area. ${ }^{(12)}$ assessed the geotechnical parameters for the formation of gully erosion in Mbaukwu town of southeastern Nigeria and observed that geotechnical investigation and laboratory analysis showed that the soil in their study area is majorly loose sand. Other research work has been carried out by ${ }^{(4,13-24)}$, on soil and its geotechnical parameters in southeastern Nigeria and other areas. ${ }^{(12)}$ stated that maximum dry density values are generally low which indicates that the soils are unconsolidated and friable. ${ }^{(13)}$ remarked that the low cation exchange capacity and low amount of fines fraction, show that soils at gully sites are loose sands, cohesionless, and are easily exposed to agents/factors of gully erosion. The gully development increases once the underlying cohesionless soil with high void ratio and low porosity is penetrated by ${ }^{(2)}$.
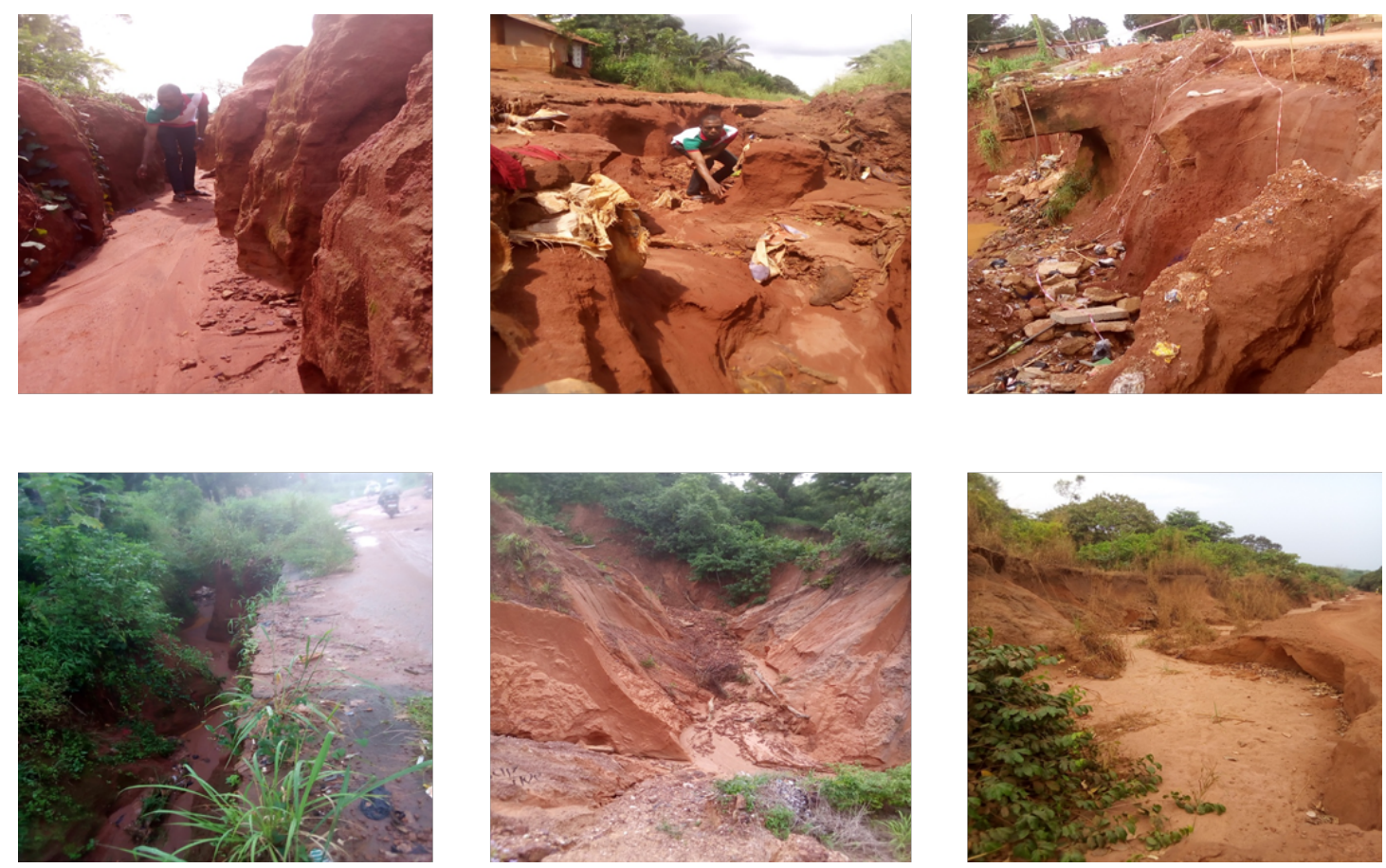

Fig 1. Part of the gully erosion within the study area.

Enugu state is one of the States located in southeastern Nigeria that have been deeply affected by gully erosion as stated by ${ }^{(1)}$. The local governments in Enugu state that are especially exposed to this erosion menace include; Igbo-Eze north, Udenu, Nsukka and Igbo-Eze south Local Government Areas. These local government areas are the major concern for this present work. Figure 1 is the part of gully menace in the study area. Hence, in this study, an attempt has been made to employ applicable 
laboratory tests to evaluate and assess properties of the soil within the gully site. The assessment mainly intended to provide geotechnical parameters that include; Atterberg limit (plastic limit, liquid limit and plasticity index), hydraulic conductivity of the soil, soil aggregate stability, particle size distribution, bulk density, total porosity of the soil and moisture content of the soil which contribute immensely to gully development and to study the influence of behavior of the sandy soil in the study area.

\subsection{Location and geology of the study area}

The study area is located in Enugu north, Southeastern Nigeria. Figure 2 shows the location map of the study area. The study area is bounded by Latitude $640^{\prime} 0^{\prime \prime} \mathrm{N}$ to $710^{\prime} 0^{\prime \prime} \mathrm{N}$ and Longitude $715^{\prime} 0^{\prime \prime} \mathrm{E}$ to $745^{\prime} 0^{\prime \prime} \mathrm{E}$. The study area encompasses four local government areas including; Igbo-Eze north, Udenu, Nsukka and Igbo-Eze south. The soil samples were collected from the major gullies such as Obollo-Etiti, Umuitodo, Ugo-Iheaka, Ekoyi Iheaka, Onuiyi road Nsukka, Alor-Uno, Olido and Ichi-Unadu gully sites. This zone belongs to Udi-Nsukka plateau, pair of plateaus in south-central Nigeria that form a nearly continuous elevated area. The Nsukka plateau, which forms the main eastward-facing escarpment, extends about 80 miles $(130 \mathrm{~km})$ from Nsukka in the north to Enugu in the south. The topography of the zone is undulating making the flow of water to be irregular in nature. There are dispersed mountains and hills within the zone, and these contributes approximately to the land slopes as well as unstable elevated geological formation in the area, which may also be attributed to either ancient tectonic activity or erosion processes.

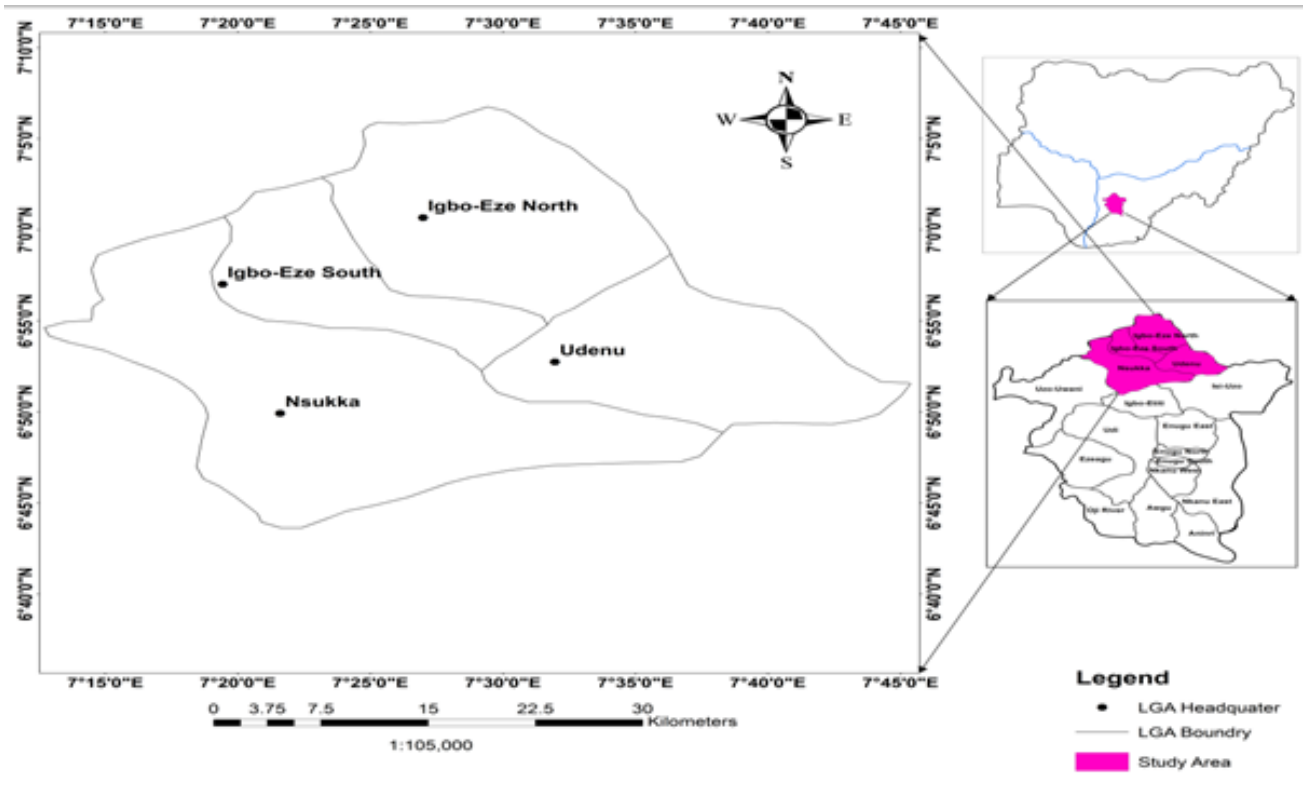

Fig 2. Location map of parts of Enugu north.

The geology of Enugu north falls under Anambra Basin which consist of six major rock formations; Enugu shale, Agwu shale, Mamu formation, Ajali formation, Nsukka formation and Imo shale formation. These rocks are grouped into four formations namely: Mamu formation, Ajali Sandstone, Nsukka Formation, and Imo Shale Formation as inferred by ${ }^{(25)}$. Sediments deposited within this time interval occur in four distinct physiographic provinces, namely the Cross River plains, the Escarpment, the Plateau and the Anambra Plains. Some of these sediments are of considerable economic importance and contain reserves of coal, natural gas, glass sands and considerable prospects for liquid hydrocarbon according to ${ }^{(26)}$. The topography is aptly defined by the Nsukka-Okigwe cuesta which stretches from Eha Alumona to Obollo Afor as its higher limit and Eha-Amufu as the lower limit. A loose sandy ferrallitic soil type occupies two thirds of the area with a loamy clay type in the remaining area. The vegetation type is the derived guinea woodland savannah with grass tufts which are deficient as soil cover. The major land use in the area is agronomy. ${ }^{(27)}$ remarked that subsistence agriculture is the predominant occupation in this vegetation zone. Buildings and road construction are other land-use. During the Benue Rift formation, the Nsukka region was part of the Anambra syncline which filled up with Upper Cretaceous (Turonian-Maastrichtian) and to minor extent Paleocene (Danian) sediments as stated by ${ }^{(28)}$ and ${ }^{(29)}$. The prominent Nsukka Cuesta was formed during the Lower Tertiary by minor compression and subsequent removal of the eastern limb of the anticline by ${ }^{(30)}$. The steep east-facing scarp forms the divide between the drainage basin of the Cross River and the River Niger. The Cuesta consists of the Ajali sandstone in the upper section 
and the Mamu lower coal measures at its base. The Ajali sandstone is composed of a very friable, medium- to coarse-grained subrounded quartz arenite in a massive herringbone cross-bedded formation of up to $540 \mathrm{~m}$ thick by ${ }^{(31)}$. White-coloured sands are overlain by red, iron- stained sands with thin interstitial, laterally persistent pale grey clay lamina by ${ }^{(32)}$ and ${ }^{(33)}$. Figure 3 shows the geology map of the study area.

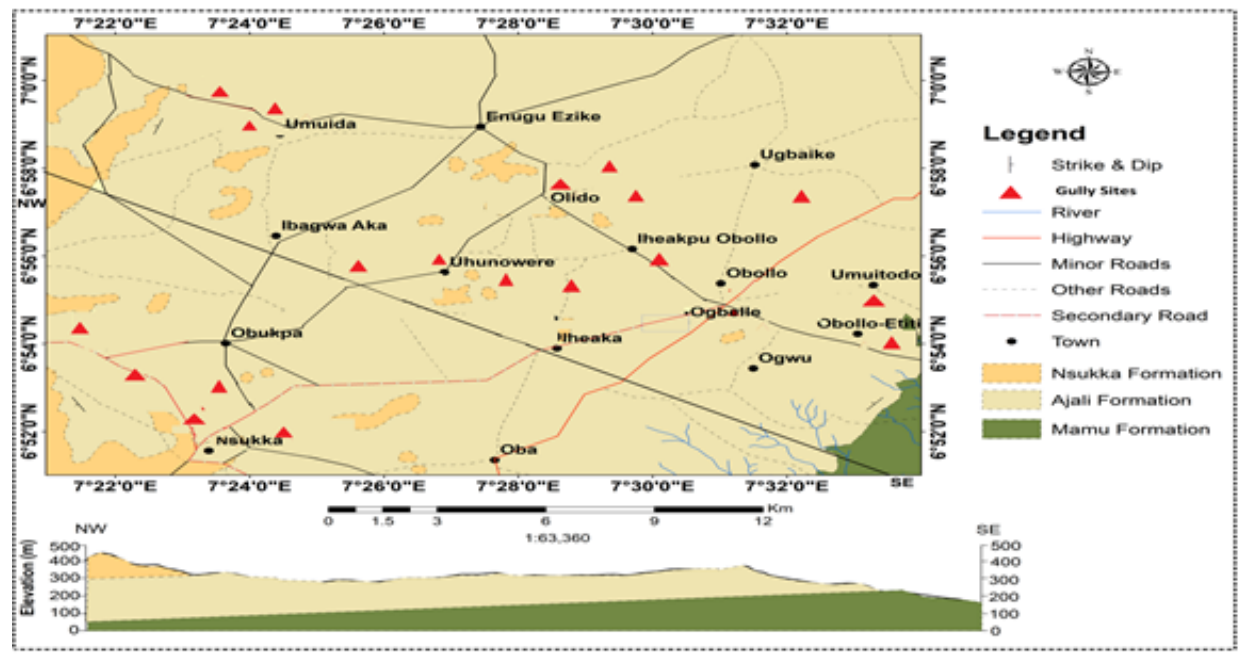

Fig 3. Geology map of the study area.

\section{Materials and Method}

In other to assess the influence of soil properties in the formation and development of gullies in the study area, geotechnical investigation were carried out which include both field and laboratory studies. Four well- distributed soil samples were collected from each major gully sites and packaged in polythene bags for laboratory analysis. The samples were collected within the depth range of 0.5 to $1.0 \mathrm{~m}$ using soil auger, five core samplers and hammer. The soil samples collected from the field were analyzed in the laboratory. The geotechnical parameters applied include; Atterberg limit (liquid limit, plastic limit and plasticity index), particle size distribution, porosity test, permeability or hydraulic conductivity test, aggregate stability, bulk density and moisture content were determined. The laboratory analyses were conducted at the Soil Science Department Laboratory of the University of Nigeria, Nsukka and were all performed in accordance with the specified standard procedures.

The Atterberg limits test are the test carried out on soil to determine the basic measurement of the nature of a fine-grained soil. This is determined by knowing the boundaries and different nature of the consistency of soil properties and moisture content based on plastic limit, liquid limit and plasticity index. The description was in terms of water content needed to produce specified degrees of consistency which could be measured. According to ${ }^{(24)}$, Liquid limit, plastic limit, plasticity index, liquidity index and relative consistency are some of the soil parameters determined through Atterberg limit test. These parameters help to determine the plasticity and clay content of a soil sample.

The Liquid Limit (LL) is the moisture content at which the soil mass flow under an applied force or the arbitrary limit of water content at which the soil is just about to pass from the plastic state into the liquid state. The LL was obtained by applying mortar with rubber-covered pestle, glass plate, liquid limit device, grooving tool and using $100 \mathrm{~g}$ of the stiff paste of soil sample thoroughly mixed with distilled water. $10 \mathrm{~g}$ of soil was removed which flowed together and weighed to $0.01 \mathrm{~g}$ and dried in an oven at $110^{\circ} \mathrm{C}$. From this, the percentages LL were obtained in the range of blows between 12 and 38 with some above and below 25 blows. The Plastic Limit (PL) determines the water content at which the behavior of a clayey soil changes from plastic to liquid or seen as the water content where soil starts to exhibit plastic behavior. This was obtained by using $15 \mathrm{~g}$ of the stiff soil paste. The soil was weighed to $0.01 \mathrm{~g}$ and dried in the oven at $110{ }^{\circ} \mathrm{C}$. The plastic limit was calculated when the soil sample begins to crumble when it reaches a diameter of $3 \mathrm{~mm}$.

Plasticity index (PI) represents the range of soil moisture content over which soil is plastic. It involves the difference between liquid limit (LL) and plastic limit. PI was achieved by applying the expression;

$$
P I=L L-P L
$$


The permeability test, which can also be called hydraulic conductivity, is the measure of the ability of water to flow through the soil. It can also be seen as a property of soil and rocks that describes the ease with which a fluid can move through the pore spaces or fractures. A flow model for this condition was developed in 1856 by Henri Darcy. He considered water flow in uniform, saturated soil column by relating the outflow per unit time to the cross sectional area of the flow channel and the difference in hydraulic heads between the inflow and outflow sections of the soil column. Undisturbed soil core sample in 7.6 $\mathrm{cm}$ cylinder, flat bottom flask equipped with $1.9 \mathrm{~cm}$ glass tubing, $250 \mathrm{~cm}^{3}$ Erlenmeyer Flask, ring stand and 2 rings, hardware cloth, glass wool, $3 \mathrm{~cm}$ rubber bands, 20 mesh sieve $7.6 \mathrm{~cm}$ in diameter were used to obtain hydraulic conductivity of the soil. A simplified and widely used mathematical relation was used to obtain hydraulic conductivity, which is of the form;

$$
q=-k \frac{\Delta H}{L}
$$

Where $\mathrm{q}$ is flux (outflow through a given cross sectional area per unit time), $\mathrm{k}$ is the hydraulic conductivity, and $\frac{\Delta H}{L}$ is the hydraulic head gradient. The permeability classes of the soil according to Soil Conservation Service (SCS) as stated by ${ }^{(34)}$ were employed in this present study.

Particle size distribution has to do with the proportions by dry mass of soil distributed over specified particle-size ranges or the rate of movement of water in the soil, that is how fast or slow water moves in the soil. The purpose of the particle size distribution that was applied in this research work is to classify soil based on the textual class, which entails whether it is predominantly sandy, loamy or clayey. Through this, the percentage of clay in the soil, silt percentage, fine sand percentage, and coarse sand percentage were determined. The soil particle size distribution was obtained with $50 \mathrm{~g}$ of the sieved sample in the dispersion cup filled with distilled water and $25 \mathrm{~cm}^{3}$ of $10 \%$ sodium hexametaphosphate solution. The following deductions were made to arrive at the particle size distribution result:

40 Seconds reading (for derivation of $\%$ sand

$$
\begin{gathered}
\left(\frac{40 \text { seconds hydrometer reading }}{\text { mass of sample }} \times 100\right) \%=\%(\text { Silt }+ \text { Clay }) \\
100 \%-(\% \text { Silt }+ \text { Clay })=\% \text { Sand }
\end{gathered}
$$

2 Hours reading (for derivation of \% clay)

$$
\begin{gathered}
\left(\frac{2 \text { hours reading }}{\text { mass of sample }} \times 100\right) \%=\% \text { Clay } \\
100 \%-(\% \text { Sand }+\% \text { Clay })=\% \text { Silt } \\
\text { Percentage of each fraction }=\frac{\text { mass of each fraction }}{\text { mass of } \mathrm{H}_{2} \mathrm{O}_{2}-\text { treated sample }} \times 100 \%
\end{gathered}
$$

Soil aggregate stability is a measure of the ability of soil to resist degradation when exposed to external forces such as water erosion and wind erosion, shrinking and swelling processes, and tillage according to ${ }^{(35,36)} .^{(37)}$ opined that aggregate stability is the combination of soil nutrient cycling, chemical and biological properties that show soil quality. Soil structural relationships are manifested in several ways including the degree of soil aggregation (aggregate stability and aggregation formation). Clay particles form into cluster through bonding forces forming large particles called aggregates. Some of these aggregates break down when subjected to action of rain, wind, agricultural management, climate, soil biological factors, wetting and drying, etc. Soil sample was dried in the oven at $60^{\circ} \mathrm{C}$ and $25 \mathrm{~g}$ of the aggregates were weighed out and sieved. The aggregate stability ending results was substituted in expression in equations below:

$$
\begin{aligned}
& \% \text { water-stable aggregates }(W S A)=\frac{\text { mass of WSA }}{\text { mass of sample }} \times 100 \% \\
& \text { Aggregate stability }=\frac{\text { mass of WSA-mass of sand }}{\text { mass of sample-mass of sand }} \times 100 \%
\end{aligned}
$$




$$
\text { Mean - weight diameter }(M W D)=\sum_{i=1}^{n} x_{i} m_{i}
$$

Where $\mathrm{n}$ is the number of sieves used (4 sieve was used), $x_{i}$ is the mean diameter of aggregates retained on the $i^{t h}$ sieve size $(\mathrm{mm})$, and $m_{i}$ is the proportion on mass basis of aggregates retained on the $i^{t h}$ sieve. The aggregates $<0.25 \mathrm{~mm}$ are said to be unstable, WSA is the water stable aggregates.

The soil porosity refers to the amount of pores, or open space between soil particles. It can also be seen as an index of the volume of pores in a soil relative to the bulk volume of the soil that is the volume of the soil in its natural state. On the other hand, soil bulk density is an indication of the degree of its looseness or compaction. It is affected by swelling and shrinking characteristics of the soil. Soil bulk density tends to increase with soil profile depth because of decreased disturbance and increased overburden. Soil bulk density can be expressed on either dry or wet basis. Since moisture content of a soil can be highly variable even within a day, expression on dry basis is deemed preferable for uniformity' sake and for ease of comparison among soils. Therefore, total porosity, bulk density and moisture content were determined using $7.6 \mathrm{~cm} \mathrm{x} 7.6 \mathrm{~cm}$ cylinders, sample bags for soil cylinders, 20 mesh sieves $7.6 \mathrm{~cm}$ in diameter, soaking pan, tension table, forced draft oven and balance. A rough average of the amount of water held by the soil between field capacity and the wilting point is $45.7 \%$ of the total water held at field capacity. This value varies with soils and the final results were obtained by using the expression in equations below:

$$
\begin{gathered}
\text { Bulk density, } \rho=\frac{\text { oven }- \text { dried mass of soil in megagrams }}{\text { volume of cylinder in cubic metre }} \\
\text { Total porosity, } \varnothing=\frac{\text { volume of water in soil at saturation }}{\text { volume of cylinder }} \\
\text { Air space porosity, } \varnothing_{a}=\frac{\text { volume of water drained at } 60 \text { cm of tension }}{\text { volume of cylinder in cubic metre }} \times 100 \\
\text { capillary porosity } \varnothing_{w}=\frac{\text { volume of water retained at } 60 \mathrm{~cm} \text { of tension }}{\text { volume of cylinder in cubic metre }} \times 100 \\
\text { Soil gravimetric moisture content, } \Theta_{m}=\frac{\text { mass of water in soil }}{\text { oven }- \text { dried mass of soil }} \times 100 \\
\text { Soil volumetric moisture content, } \Theta_{v}=\frac{\text { volume of water in soil }}{\text { volume of cylinder }} \times 100 \\
\text { Cof available water in a metre of soil }=\frac{\Theta_{v}}{100} \times 0.457 \times 100 \mathrm{~cm}
\end{gathered}
$$

\section{Results and discussion}

hows the summary results of the particle size distribution samples. The soil classification shows that the textural characteristics were predominantly sandy, loamy or clayey, with percentage clay ranged from 8 to 18\%, percentage silt ranged from 3 to $9 \%$, percentage fine sand ranged from 20 to $38 \%$ and percentage coarse sand ranged from 29 to $69 \%$. The particle size distribution results indicate that the study areas were majorly dominated with fine and coarse sandy soil with low amount of layers of clay and silt in such small proportion. The implication is that the presence of this sandy soil contributes immensely to the gully erosion menace in the area, as its porosity and permeability nature are weak to erosion protective capacity. These agree with ${ }^{(38)}$ who observed that the soil that is generally poorly sorted with poor drained material decreases in cohesion and resistance to soil cracking. 
Table 1. Summary result of particle size distribution.

\begin{tabular}{llllll}
\hline Sample Description & Textual Class & \% Clay & \% Silt & \% Fine Sand (F.S) & \% Coarse Sand (C.S) \\
\hline IGBO-EZE SOUTH L.G.A & Sandy Loam & 14 & 3 & 38 & 45 \\
IGBO-EZE NORTH L.G.A & Loam Sand & 8 & 3 & 22 & 67 \\
NSUKKA L. G. A & Sandy Loam & 18 & 9 & 44 & 29 \\
UDENU L. G. A & Loam Sand & 8 & 3 & 20 & 69 \\
\hline
\end{tabular}

Table 2 shows the summary result of Atterberg Limit.The liquid and plastic limits results were used to obtain the plasticity index result which is a measure of the plasticity of the soil. The laboratory result of percentage liquid limit (LL) ranges from 16.67 to $46.89 \%$, percentage plastic limit (PL) values of $33.45 \%$ in Igbo-Eze south and $22.38 \%$ in Nsukka were depicted. None plastic limit were observed in Igbo-Eze north and Udenu. Percentage plasticity index (PI) of $13.44 \%$ in Igbo-Eze South and 9.90\% in Nsukka were estimated, while zero plasticity indexes in Igbo-Eze North and Udenu were observed. The LL samples for Igbo-Eze north and Udenu were NP (Non plastic), therefore their corresponding plasticity indexes (PI) were zero; and this correspond to ${ }^{(39)}$. The NP result indicates that the soil of the gully from where the samples were taken is loose, friable, low binding materials and less cohesive. However, the gully samples of Igbo-Eze south and Nsukka were observed to have low value of plastic limit which are in accordance with ${ }^{(40)}$, who pointed out that $\mathrm{PL}<35 \%$ should be considered low plasticity indicating low content of fine materials and also shows that the soil in the area may change from one state of consistency to another with minimum change in water content. Consequently, Nsukka and Igbo-Eze south gully samples showed low and medium plasticity index respectively. These were confirmed from the work of ${ }^{(39)}$ that the medium value is an indication that the soil content in the area is relatively stable compared to other samples. The low value shows that the soil within the area has high rate of instability and susceptible to erosion. Therefore, from the observation of the four sample results, the soil is non-cohesive and non-plastic, which are the soil properties that contribute immensely to the gully menace in the area. The same factors create room with which the water flow with ease with increase in velocity, moving soil particle down to other side and creating deep gully because of less or no resistive materials. ${ }^{(41)}$ opined that the rate of detachment of soil particles decreases as the extent of cementation increases.

Table 2. The Summary of soil Atterberg Limit

\begin{tabular}{llllllllll}
\hline $\begin{array}{l}\text { Sample } \\
\begin{array}{l}\text { Descrip- } \\
\text { tion }\end{array}\end{array}$ & $\begin{array}{l}\text { No. of } \\
\text { Blows }\end{array}$ & $\begin{array}{l}\text { Empty } \\
\text { weight of } \\
\text { can }\end{array}$ & $\begin{array}{l}\text { Fresh } \\
\text { weight of } \\
\text { can }\end{array}$ & $\begin{array}{l}\text { Oven dry } \\
\text { weight of } \\
\text { can }\end{array}$ & $\begin{array}{l}\text { Weight of } \\
\text { moisture }\end{array}$ & $\begin{array}{l}\text { Oven dry } \\
\text { weight of soil } \\
\text { only }\end{array}$ & $\begin{array}{l}\text { \% Liquid } \\
\text { Limit(LL) }\end{array}$ & $\begin{array}{l}\text { \% Plastic } \\
\text { limit (PL) }\end{array}$ & $\begin{array}{l}\text { Plasticiy } \\
\text { Index } \\
\text { (IP) }\end{array}$ \\
\hline $\begin{array}{l}\text { Igbo-Eze } \\
\text { south }\end{array}$ & 21 & 16.96 & 22.16 & 20.50 & 1.66 & 3.54 & 46.89 & 33.45 \\
$\begin{array}{l}\text { Igbo-eze } \\
\text { north }\end{array}$ & 10 & 16.12 & 24.51 & 23.36 & 1.15 & 7.24 & 15.88 & NP & 0 \\
$\begin{array}{l}\text { Nsukka } \\
\text { Udenu }\end{array}$ & 16 & 15.15 & 22.65 & 20.82 & 1.83 & 5.67 & 32.28 & 22.38 & 9.90 \\
\hline
\end{tabular}

Table 3 is the summary table for percentage soil aggregate stability for the four gully samples. It ranges from 10.68 to $45.59 \%$. The result indicates that the gully samples from Igbo-Eze north, Nsukka and Udenu with moderate stability show that within these areas, the samples have the ability to resist to some certain extent the degradation when exposed to external forces such as water erosion, wind erosion, shrinking and swelling process. Therefore, the textural class dominated in these areas is more of clay soil, because clay particles form into cluster through bonding forces to form large particles called aggregates. The gully sample located within Igbo-Eze south with low aggregate stability value of $10.48 \%$ indicates that the soil structures in these areas are unstable and have less or no resistive capacity to degradation when exposed to external forces like water erosion, wind erosion, etc, and is suspected to have textural class of sandy loam. 
Table 3. The percentage of Soil Aggregate Stability.

\begin{tabular}{|c|c|c|c|c|c|c|c|c|}
\hline $\begin{array}{l}\text { Sample Descrip- } \\
\text { tion }\end{array}$ & $2 \mathrm{~mm}$ & $1 \mathrm{~mm}$ & $0.5 \mathrm{~mm}$ & $0.25 \mathrm{~mm}$ & $<25 \mathrm{~mm}$ & $\begin{array}{l}\text { Weight of } \\
\text { sand }\end{array}$ & $\begin{array}{l}\text { Mean weight diame- } \\
\text { ter }(\mathrm{mm})\end{array}$ & $\begin{array}{l}\% \text { Aggregate } \\
\text { stability }\end{array}$ \\
\hline \multirow{2}{*}{ Igbo-Eze south } & 1.41 & 1.12 & 4.01 & 8.95 & 9.51 & 4.38 & - & 10.68 \\
\hline & 0.19035 & 0.0672 & 0.1203 & 0.13425 & 0.04755 & - & 05595 & - \\
\hline \multirow{2}{*}{ Igbo-eze North } & 6.19 & 3.04 & 4.67 & 6.64 & 4.46 & 7.01 & - & 38.30 \\
\hline & 0.83565 & 0.1824 & 0.1401 & 0.0996 & 0.0223 & - & 1.2801 & - \\
\hline \multirow{2}{*}{ Nsukka } & 7.16 & 2.58 & 3.36 & 4.19 & 7.71 & 3.13 & - & 45.59 \\
\hline & 0.9666 & 0.1548 & 0.1008 & 0.06285 & 0.03855 & - & 1.3236 & - \\
\hline \multirow{2}{*}{ Udenu } & 1.05 & 3.44 & 5.12 & 7.90 & 7.43 & 7.90 & - & 34.20 \\
\hline & 0.14175 & 0.2064 & 0.1536 & 0.1185 & 0.03745 & - & 0.6577 & - \\
\hline
\end{tabular}

Table 4 shows the summary results of hydraulic conductivity, soil bulk density, total porosity and moisture content of the soil. The percentage medium moisture content were observed within Nsukka gully sample and Igbo-Eze south gully sample with percentage moisture content values of $31.75 \%$ and $24.38 \%$ respectively. These results show that the soil texture within these areas contains slightly a volume of clay soil that tends to retain or hold water a little while. The moisture content shows a decrease in value within Igbo-Eze North and Udenu gully samples with percentage moisture content of $7.07 \%$ and $8.34 \%$ respectively. The low moisture content value shows that the soils are loose and hence cannot hold much water longer enough. Therefore, the low moisture contents of the subsurface soils lead to low capacity for water retention during rainfall. According to ${ }^{(42)}$, such low moisture contents causes breakdown on the grain-to-grain forces that existed in the soil. The soil bulk density test conducted on the four gully samples varies from 1.39 to $1.56 \mathrm{~g} / \mathrm{cm}^{3}$. The results indicate that the bulk density of soil is relatively low, poorly consolidated, and this indicates that the soils are not compacted but very loose and therefore prone to erosion. The value of these bulk density values are within the low value range as stated by ${ }^{(24)}$. However, the value percentage of total porosity ranged from 41.13 to $47.55 \%$. The results show that the gully sample within Igbo-Eze south and Nsukka have relatively medium porosity, which indicates that the soil particle texture contains more of sandy soil which have larger macro-pores. Within Igbo-Eze north and Udenu, the porosity values were seen to have a little decrease in porosity value which indicates that the soil contains more of fine textures such as clay or silt soil which has micro porosity. Therefore, it is pertinent to state that finely textured soils like clay or silt with micro-pores and coarse soil such as sandy soil with macro-pores can have large pores known as bio-pores. These bio-pores are the spaces between soil particles created by termites, earthworms or decaying plant roots. These large pores increase the rate at which water permeate the soil, and therefore, increases the rate at which the erosion occur in the area. In the same way, the hydraulic conductivity which determines how the fluid passes through the pores and fractured rocks has range of values from 8.89 to $22.73 \mathrm{~m}$ /day. These results indicate that area with low value of conductivity were majorly dominated with silt, clay soil or the compatibility of soil is high, whereas area with relatively increase in hydraulic conductivity value shows that the textural class is more of loose materials such as sandy soil or the area with more of biological activities like decays of roots crop and activities of other insect. ${ }^{(43)}$ states that the hydraulic conductivity is estimated based on grain size or published range of values for common geological media. Therefore, the relatively high range of value of hydraulic conductivity shows that the area has low protective capacity and hence increases erosion in the area.

Table 4. Summary results for hydraulic conductivity, bulk density, porosity and moisture content.

\begin{tabular}{llllll}
\hline S/N & Sample Description & $\begin{array}{l}\text { Hydraulic Conductivity (Perme- } \\
\text { ability) }(\mathrm{m} / \text { day) }\end{array}$ & $\begin{array}{l}\text { Bulk } \\
\left(\mathrm{g} / \mathrm{cm}^{3}\right)\end{array}$ & $\begin{array}{l}\text { Density } \\
\text { \% Total Porosity }\end{array}$ & $\begin{array}{l}\text { Moisture Con- } \\
\text { tent }\end{array}$ \\
\hline 1 & Igbo-Eze south L.G.A & 8.89 & 1.39 & 47.55 & 24.38 \\
2 & Igbo-Eze north L.G.A & 16.16 & 1.56 & 41.13 & 7.07 \\
3 & Nsukka L. G. A & 14.14 & 1.45 & 45.28 & 31.75 \\
4 & Udenu L. G. A & 22.73 & 1.55 & 41.51 & 8.34 \\
\hline
\end{tabular}

However, the geotechnical survey results involving; Atterberg limit, soil aggregate stability, particle size distribution, hydraulic conductivity, bulk density, total porosity and percentage moisture content obtained in parts of Enugu north, which is located in Anambra Basin, Southeastern Nigeria, shows that samples from Udenu and Igbo-Eze north (Table 1 ) have more of coarse sand that form major contribution to the menace of gully erosion in the area. More fine sand is mostly seen within the samples of Nsukka and Igbo-Eze south. These results agree with the work of ${ }^{(2)}$ that Southeastern Nigeria are mostly loosed sands with low percentage of silt/clay fractions which causes gully erosion in the area. The non plastic liquid limit observed in Igbo- 
Eze north and Udenu samples indicates that the characteristics of soil within the area is loosed, friable, low binding materials and are less cohesive, which implies that the soil particles detach with ease as the soil do not have any resistive material. This is in agreement with $^{(13)}$ that when soil is more of loosed sand showing cohesionless characteristics, they are easily exposed to agents of gully erosion. In Igbo-Eze south, sample indicates that the soil is unstable which contributes to the erosion menace in the area. It is worthy to note that the increase of soil pores in some study area was induced by other characteristics of bio-activities like termites, earthworm and decaying plant root. When these bio-activities take place in such area, it then increases the rate at which water permeate the soil and increase erosion rate in the area.

\section{Conclusion}

The geotechnical analysis carried out in parts of Enugu north, depicts that there are factors responsible for the menace of gully erosion in the area. The presence of coarse sand, fine sand and low amount of clay and silt in small proportion greatly influences the gully erosion in the area. Another major contributing factor to the increase of erosion in the area is the loosed characteristics of the soil, its friability and low binding materials with less cohesive. Instability of soil structure and low moisture content as observed also influences the rate of erosion in the area. Bio-activities such as termites, earthworm and decaying plant roots are other factors that must be looked at, because they increase the porosity of the soil and then make water permeate so easily to the soil and increase the rate at which erosion occur in the area. Consequently, adequate control measures such as engineering aspect of soil control including; check-dams, construction of ditches, maintenance of roads and drainage system should be employed to control erosion in these areas. Afforestation and other agro programs should be introduced to protect the soil from direct impact of raindrops and runoff and maintain the moisture content and as well as stability of the soil structure in the area.

\section{Conflict of Interest}

There is no conflict of interest

Authors Contribution: These are the authors and their contribution;

O. U. E. (Ph.D. student) conducted all the experiments and wrote the manuscript.

D. N. O. (Professor) wrote some parts and revised the manuscript.

F. N. O. (Professor) revised the manuscript.

J. C. I. (Ph.D) wrote some parts and revised the manuscript.

\section{References}

1) Egbueri JC, Ogbonnaya I. The impact of hydrogeomorphological characteristics on gullying processes in erosion-prone geological units in parts of southeast Nigeria. . Geology, Ecology, and Landscape. 2020;5(3). Available from: https://doi.org/10.1080/24749508.2020.1711637.

2) Okengwo ON, Okeke OC, Okereke CN, Paschal AC. Geological and Geotechnical Studies Of Gully Erosion at Ekwulobia, Oko and Nanka Towns, Southeastern Nigeria. Electronic Journal of Geotechnical Engineering. 2015;20(1):113-122.

3) Umoru CI, Shuaibu AM, Abdullahi IN, Umar MU. Geotechnical Assessment of Gully Erosion at Ankpa Area, North Central Nigeria. Journal of Applied Chemistr. 2015;8(12):36-48. Available from: http://www.iosrjournals.org/iosr-jac/papers/vol8-issue12/Version-1/F081213648.pdf.

4) Okoyeh EI, Akpan AE, Egboka B, Okeke HI. An Assessment of the Influences of Surface and Subsurface Water Level Dynamics in the Development of Gullies in Anambra State. Southeastern Nigeria Earth Interactions. 2014;4:1-24. Available from: https://doi.org/10.1175/2012EI000488.1.

5) Amangabara GT, Otumchere VN. Understanding the Factors and Processes of the Umuagwo -Urualla Gully Erosionin Ideato North LGA of Imo State. Nigeria Journal of Scientific and Engineering Research. 2016;3:55-67. Available from: https://jsaer.com/understanding-the-factors-and-processes- of-theumuagwo-urualla-gully-erosionin-ideato-north-lga-of-imo-state-nigeria/.

6) Obi NI, Okekeogbu CJ. Erosion Problems and their Impacts in Anambra State of Nigeria: (A case of Nanka community). International Journal of Environment and Pollution Research. 2017;1:24-37.

7) Obiadi II, Nwosu CM, Ajaegwu NE, Anakwuba EK, Onuigbo NE, Akpunonu EO. Gully Erosion in Anambra State, South East Nigeria: Issues and Solution. International Journal of Environment Sciences. 2011;2:795-804.

8) Nwilo PC, Olayinka DN, Uwadiegwu I, Adzandeh AE. An Assessment and Mapping of Gully Erosion Hazards in Abia State: A GIS Approach. Journal of Sustainable Development. 2011;4:196-211. Available from: https://doi.org/10.5539/jsd.v4n5p196.

9) Adekalu KO, Olorunfemi IA, Osunbitan JA. Grass mulching effect on infiltration, surface runoff and soil loss of three agricultural soils in Nigeria. Bioresource Technology. 2007;98:912-917. Available from: https://doi.org/10.1016/j.biortech.2006.02.044.

10) Amah JI, Aghamelu OP, Omonona OV, Onwe IM. A study of the dynamics of soil erosion using rusle2 modelling and geospatial tool in Edda-Afikpo Mesas, South Eastern Nigeria. Pakistan Journal of Geology. 2020;2020(4):56-71. Available from: https://doi.org/10.2478/pjg-2020-0007.

11) Abdulfatai IA, Okunlola IA, Akande WG, Momoh LO, Ibrahim KO. Review of Gully Erosion in Nigeria: Causes, Impacts and Possible Solutions. Journal of Geosciences and Geomatics. 2014;2:125-129. Available from: http://article.geosciencesgeomatics.com/pdf/jgg-2-3-8.pdf.

12) Chikwelu EE, Ogbuagu FU. Geotechnical Investigation of Soil around Mbaukwu Gully Erosion Sites, South-Eastern Part of Nigeria. Journal of Applied Geology and Geophysics. 2014;2:6-17. doi:10.9790/0990-0240617.

13) Amagu AC, Eze SN, Jun-Ichi K, Nweke MO. Geological and Geotechnical Evaluation of Gully Erosion at Nguzu Edda, Afikpo Sub-Basin, Southeastern Nigeria. Journal of Environment and Earth Science. 2018;8:148-158. Available from: https://iiste.org/Journals/index.php/JEES/article/view/45748. 
14) Ocheli A, Ogbe OB, Aigbadon GO. Geology and geotechnical investigations of part of the Anambra Basin, Southeastern Nigeria: implication for gully erosion hazards. Environmental Systems Research. 2021;10:1-6. Available from: https://environmentalsystemsresearch.springeropen.com/articles/10. 1186/s40068-021-00228-2.

15) Amah EA, Esu EO, Kanu EO. Hydrogeological and Geotechnical Investigations of Gully erosion sites in Calabar area. Southeastern Nigeria Global Journal of pure and Applied Sciences. 2008;14:423-431. Available from: https://doi.org/10.4314/gjpas.v14i4.16832.

16) Okorafor OO, Akinbile CO, Adeyemo AJ. Soil erosion in South Eastern Nigeria: A Review. Scientific Research Journal. 2017;2017(5):30-37. Available from: https://www.researchgate.net/publication/323278153.

17) Nwankwoala HO, Igbokwe T. Assessment and mapping of gully erosion geo-hazards in Agulu - Nanka, Southeastern Nigeria: An Integrated Geotechnical and GIS Approach. An International Scientific Journal. 2020;(146):236-254. Available from: http://psjd.icm.edu.pl/psjd/element/bwmeta1.element.psjdde9cb068-0bd4-48a6-bded-dc7b662caa82.

18) Imasuen OI, Omali AO, Ibrahim I. Assessment of environmental impacts and remedies for gully erosion in Ankpa Metropolis and environs Nigeria. Advances in Applied Science Research. 2011;2:372-384.

19) Amos CU, John UJ. Geophysical and Geotechnical Evaluation of Erosion Sites in Ebem-Ohafia Area of Abia State, Southern Nigeria. Advances in Research. 2017;10:1-14. Available from: https://doi.org/10.9734/AIR/2017/31538.

20) Egbueri JC, Igwe O, Unigwe CO. Gully slope distribution characteristics and stability analysis for soil erosion risk ranking in parts of southeastern Nigeria: a case study. Environ Earth Sci. 2021;80:292-292. Available from: https://doi.org/10.1007/s12665-021-09605-7.

21) Igboekwe MU, Eke AB, Adama JC, Ihekeaba G. The use of vertical electrical sounding (VES) in the evaluation of erosion in Abia state University, Uturu and its environs. The Pacific Journal of Sciences and Technology. 2012;13:509-520. Available from: http://www.akamaiuniversity.us/PJST13_2_509.pdf.

22) Egboka BC, Orji A, Nwankwoala HO. Gully Erosion and Landslides in Southeastern Nigeria: Causes, Consequences and Control Measures. Global Journal of Engineering Sciences. 2019;2(4):1-11. Available from: http://dx.doi.org/10.33552/GJES.2019.02.000541.

23) Olawuyi AK, Abolarin SB. Evaluation of Vertical Electrical Sounding Method for Groundwater Development in Basement Complex Terrain of WestCentral Nigeria. Nigeria Journal of Technological Development. 2013;2:22-28. Available from: https://www.ajol.info/index.php/njtd/article/view/117671.

24) Okunlola IA, Abdulfatai IA, Kolawole LL, Nwanosike AA. Geological and Geotechnical Investigation of Gully Erosion along River Bosso. Journal of Geosciences and Geomatics. 2014;2:50-56.

25) Adetona AA, Abu M. Estimating the Thickness of Sedimentation within Lower Benue Basin and Upper Anambra Basin, Nigeria, Using Both Spectral Depth Determination and Source Parameter Imaging. Geophysics. 2013;p. 1-10. Available from: http://dx.doi.org/10.1155/2013/124706.

26) Obiora DN, Ossai MN, Okwoli E. A case study of aeromagnetic data interpretation of Nsukka area, Enugu State, Nigeria, for hydrocarbon exploration. International Journal of Physical Sciences. 2015;10:503-519. Available from: https://doi.org/10.5897/IJPS2015.4392.

27) John UJ, Igboekwe MU, Uhegbu CA. Geophysical Evaluation of Erosion Sites in some Parts of Abia State, Southeastern Nigeria. Physical Science International Journal. 2015;6(2):66-81. Available from: https://doi.org/10.9734/PSIJ/2015/13821.

28) Benkhelil J. Structure et evolution geodynamique du bassin intracontinental de la Benoue (Nigeria). International Journal of Geosciences. 1986;12:30-128.

29) Popoff M, Doucet JF, Latil-Brun MV. Analyse de la subsidence au Creâtace superieur-Paleoce dans le basin d'Anambra, SW du fosse de la Benoue. Comptes Rendus des Seances de l'Academie des Sciences. 1988;307:1271-1276.

30) Pritchard JM. Landform and Lanscape in Africa. 1979;p. 151-152. Available from: https://catalogue.nla.gov.au/Record/2859292.

31) Ladipo KO, Boer PLD. Tide-influenced sedimentary environments and facies. Extended versions of papers presented at the Symposium on Classic Tidal Deposits. 1985; p. 333-340.

32) Okwu-Delunzu VU, Iwueke NT, Aniagolu CO. Gully Erosion and its Environmental Impact in Eke, Udi Local Government Area of Enugu State. Environment and Ecology Research. 2018;6(5):507-517. Available from: http://dx.doi.org/10.13189/eer.2018.060511.

33) Nnam V. Assessment of the Magnitude of Gully Erosion in Enugu Urban Area using Revised Universal Soil Loss Erosion Model (RUSLE). African Research Journal of the Environment. 2019;p. 16-23. Available from: https://publishingrealtime.com/files/b6acb191_0122.pdf.

34) Lewis MA, Cheney CS, Odochartaigh BE. Guide to permeability indices. British Geological Survey. 2006;1(20). Available from: http://nora.nerc.ac.uk/id/ eprint/7457/.

35) Papadopoulos A, Bird NRA, Whitemore AP, Mooney SJ. Investigating the effect of organic and conventional management on soil aggregate stability using x-ray computed tomography. European Journal of Soil Science. 2009;60:360-368. Available from: https://onlinelibrary.wiley.com/doi/abs/10.1111/j.13652389.2009.01126.x.

36) USDA National Resources Conservation Service. Soil quality indicators: Aggregate stability. 1996.

37) Doran JW, Jones AJ. Qualitative indicators of soil quality: A minimum data set. SSSA Special Publication. 1996. Available from: https://agris.fao.org/agrissearch/search.do?recordID=US201300917194.

38) Akpokodje EG. Introduction to Engineering Geology. Journal of Water Resource and Protection. 2001;8(3):259-259.

39) Das BM. Advanced Soil Mechanics. 2nd ed.. 1997. Available from: https://www.scribd.com/document/3102781/Das-B-M-1997-Advanced-SoilMechanics-2nd-edition.

40) Emeh CO, Igwe O. Variations in soils derived from an erodible sandstone formation and factors controlling their susceptibility to erosion and landslide. Journal of the Geological Society of India. 2017;90(3):362-370. Available from: https://link.springer.com/article/10.1007/s12594-017-0725-5.

41) Rockwell DL. The influence of groundwater on surface flow erosion processes during a rainstorm. Earth Surface Processes and Landforms. $2002 ; 27: 495-514$. Available from: https://onlinelibrary.wiley.com/doi/abs/10.1002/esp.323.

42) Okagbue CO, Ezechi JO. Geotechnical Characteristics of Soils Susceptible to Severe Gullying in Eastern Nigeria. Bulletin of the International Association of Engineering Geology. 1988;38:111.

43) Nwankwoala HO, Igbokwe T. Assessment and mapping of gully erosion geo-hazards in Agulu - Nanka, southeastern Nigeria: An integrated geotechnical and gis approach. An International Scientific Journal. 2020;p. 236-254. 